\title{
Extensive reading to improve students' writing of explanation text
}

\author{
${ }^{1}$ Siti Nur Aida, ${ }^{1 E l o k}$ Widiyati* \\ ${ }^{1}$ English Education Study Program, Faculty of Languages and Communication Science, \\ Universitas Islam Sultan Agung, Indonesia
}

*Corresponding Author

widiyati@unissula.ac.id

\begin{abstract}
This research aims at finding out whether or not the use of extensive reading is effective for teaching writing explanation text to the eleventh grade at Islamic University in Semarang. Quasi experimental research was applied as the method. The researchers took two groups as the sample, they were XI MIPA 6 as the experimental class and XI MIPA 2 as the control class. The total subject of this research was 65. This research used SPSS in analysing the data of writing test through several activities. They were pre-test before treatments, and post-test after treatments. The result of the research shows the significance difference in the writing ability of explanation text between eleventh-graders who were taught by using extensive reading and those were not taught by using it. It can be seen in the result of mean score in the post-test of experimental class which is 64.4118 and control class which is 48.5484 and as a result Sig. (2-tailed) is $0.00<0.05$. Therefore, the null hyothesis of this research is rejected. It means that the use of extensive reading had significantly improved the eleventh-graders' writing ability of the explanation text in English teaching and learning process of the experimental class at Islamic School in Semarang in the academic year $2018 / 2019$.
\end{abstract}

Keywords: Extensive reading; writing; explanation text

Received: Revised: Accepted: Published:

8 October $2019 \quad 27$ February $2020 \quad 28$ February $2020 \quad 29$ February 2020

\section{INTRODUCTION}

Language is the most important means of communication in our life because it can help us to communicate with each other. English is very important now because it is international language. In many countries such as India, Singapure, and Malaysia, English becomes their second language.

There are four English skills to be learned, namely, listening, speaking, reading, and writing. Reading and listening become receptive skills. Speaking and writing become productive skills. As receptive skills, listening and reading 
Aida, S.N., \& Widiyati, E. (2020). Extensive reading to improve students' writing skill of explanation text. EduLite: Journal of English Education, Literature, and Culture, 5 (1), 109-117. DOI: http://dx.doi.org/10.30659/e.5.1. 109-117

are utililized in getting data. To the extent receptivity is concerned, it is the most widely recognized human quality, likewise with the birth itself, the kid begins accepting different impressions through its detects (Broughton, 1978). The limit of listening is at the plain heart of all progress, formal guidance is given from birth, when the more learning, the more is also obtained (Brown, 2011). Therefore, improving reading and listening as receptive skills is very important to learn to get the best learning.

Reading is a reasoning under the actuation of printed page and is viewed as a psycho phonetic foreseeing amusement. It must be perceived that reading as a receptive skill in written mode as well, is a mind good ability that is to state that it includes an entire arrangement of skill. As productive skills, speaking and writing are valuable for creating and passing information. Writing is a productive skill in written mode. Aghanjaloo \& Khosravi (2016) state that when we talk about writing there is generally two-path refinement of writing: institusional and individual writing. Institusional writing incorporates course books, reports, applications, business correspondence though individual writing covers individual letters and creative writing.

Reading is always an important action. Readers always read something for a reason. This procedure always includes sentiments just as information and experience. It can never be isolated from the goals and interests of readers or from the outcomes that it has on them (Smith, 1994). Reading is an exchange from brain to mind. The reader gets the benefits of reading with their own methods.

In foreign language teaching, two methodologies of reading are perceived: intensive reading and extensive reading. Intensive reading approach manages short messages under a teacher's direction for detailed comprehension. The intensive reading technique is reading for a high level of knowledge and maintenance over an extensive stretch of time. Extensive reading manages moderately long massages. Data and general comprehension are reasons for extensive reading. Having a reasonable methodology between these two is the most basic component in foreign language reading program.

In this research, the researchers focused on extensive reading. Palmer (1927, as cited in Smith, 2003, 454) who is the originator of the term characterizes that extensive reading implies 'quick reading'. The readers who have foreign language measurements, can read texts in the foreign language with comprehension without opening the dictionary often. Palmer considers regular utilization of a dictionary as an awful phonetic propensity. West (1955, 189) states that while making advantageous readers, alluded to the point of reading extensively, to present more noteworthy office in the utilization of the vocabulary previously picked up, to give the kid a feeling of accomplishment and an essence of the joy to be gotten from his achievement. Therefore, the students used extensive reading to get a quick understanding without opening the dictionary.

Writing is the one of the essential abilities of English. Writing is more complicated than the other language skills. It is commonly considered a standout amongst the most troublesome that different abilities for remote language of the students. Indeed, even native speakers feel trouble in appearing great order of writing. According to Johnstone, Ashbaugh, \& Warfield (2002), the ESL teachers incorporate writing skill in the syllabus 
because this is a basic component for students' academic success. Therefore, students need more practice in writing to improve their writing skills, so students do not think that writing is difficult.

One extent of English learning at senior high schools is that students can comprehend and create a short practical content and short expositions as certain content kinds. They are procedure, descriptive, recount, narrative, report, news item, analytical exposition, hortatory exposition, spoof, explanation, discussion, and review based on the Curriculum 2013 . In this research, the researchers focused on improving students' ability in writing an explanation text because it is one of the texts which taught in the eleventh grade. The researchers additionally understand that writing an explanation text was not a simple activity. Through this research, the students were required to have the capacity to deliver explanation texts fittingly.

Based on the explanation above, writing skill really supports the students' ability in creating explanation text. Moreover the researchers were interested in finding out the effectiveness of extensive reading to improve students' writing explanation text.

\section{Writing skill}

Writing is presumably the etymological ability that is least utilized by a great many people in their local language (Davies, 2008, 96). Writing is a movement that utilizations to enable understudies to practice and to work with language they have been examining. It is a process where the understudies are tested to locate the best method to express their thought into some composition.

Daiute (1985) in Brady (1990) states that writing is the augmentation of reasoning and talking. This is the way towards intuition move into written structure. Therefore, writing is more difficult than speaking. Nunan $(2003,88)$ states that writing is the psychological work of creating thoughts, pondering how to express them, and arranging them into explanations and passages that will be obvious to a reader. Therefore, the learners need an inspiration before writing. This is the difficult work from the learners. However, if the learners have a good idea to write, it is not a big problem for them.

Those are every one of the clarifications from the specialists and the researchers can infer that writing is an action that gives us more space to express our emotions or thought. Recorded as a hard copy, the understudies should ready to deliver words, and afterward relate them into sentences and organize them into great sections.

\section{Explanation text}

According to Anderson and Anderson (1997, 80), explanation text is the clarifying content sort explains to how or why something happens. It takes a gander at the means instead of the things. The goal of an explanation text is to tell each progression of the procedure (the how) and to give reasons (the why). Explanation is a bit of content that bargains with the procedures engaged with comprehension and making explicit the how or why of particular phenomena, events, and ideas happen in logical and specialized fields. Grammatical features in explanation text incorporate passive voice, simple present tense, conjunctions of time and cause, noun groups and complex sentences. 
Aida, S.N., \& Widiyati, E. (2020). Extensive reading to improve students' writing skill of explanation text. EduLite: Journal of English Education, Literature, and Culture, 5 (1), 109-117.

There are three stages for developing a written explanation according to Anderson and Anderson $(1997,80)$. The first step is a general declaration about the event or thing that will be clarified. At that point, a progression of paragraphs that tell the hows or whys. In this paragraph, the writer tells the succession of explanation text. The last advance is a finishing up section as an end. It can be concluded that the writer has clarified in this paragraph.

The good explanation text need some grammatical features in forming the text. The principal thought is the utilizing of simple present tense to clarify why something accured. The action words in simple present tense will change by including 's' if the subjects of the sentence are 'she, he, it'; for for example go progresses toward becoming goes. The second thought is the utilizing of passive voice which is usually used when the object of the action could really compare to the individuals who play out the action. Next, it needs to consider the utilizing of explanation text to give insights concerning what, how and why something occured and utilizing of of cause and effect words to show the explanation of phenomenon likes because, caused by, as a result of, and an effect of.

\section{Reading skill}

As we realize that reading is one of English skills that is needed by readers understand a text. In this sense, Nuttal $(2005,3)$ perceives that reading is basically concentrating on purposing, particularly conveying meaning from writer to reader. By definition, the reading action will improve thinking cooperatively among the reader, the writer, and the text.

Al-Khulli $(1997,69)$ in Haq $(2011,12)$ states that reading comprises as a procedure to acquire much data and get to importance from written materials. This infers that reading gives an opportunity for readers to comprehend the text. Reading is systems utilized to urge the readers to read with hope and foresee the author's consideration. Moreover, Finochiaro and Bonomo (1973: $119)$ state that reading is bringing importance to and getting significance from printed or written material.

Reading has numerous advantages not only in reading skill, but also the other skill of students. Mickulecky, et al (1996) express that reading as a microcosm of four skils, has four benefits such as:

1. Helping students to improve their writing,

2. Helping students learn to think English,

3. Helping students to find out about new idea, facts, and experiences,

4. Enlarging students' English vocabulary.

From the four benefits above, reading has a big influence on other fields. Therefore, if the quality of reading is getting better, the effect will also be better too for students.

\section{METHOD}

This research is a quantitative experimental research approach. Chinelo (2016)states that experimental research is a research which focuses on the causes between dependent and independent variables. This type of research seeks to find the effect of changes in the independent variable on the dependent variable. 
The subject of this study consists of the population and sample. According to Pandey \& Pandey (2015), population is the entire mass of a research or can be defined as the main group which the sample was taken. The population of this research is the eleventh graders of Islamic School in Semarang in the academic year 2018/2019.

According to Nakayama et al. (2007), sample is the smaller group of population. The sample of this research was devided into two classes, they are experimental and control classes. In addition, this research used purposive random sampling to take the sample of the research. In addition, this research took sample based on the knowledge or the experience of researcher. It also can be done based on the English teacher's recomendation.

Before collecting data, the researcher must make an instrument. According to Airasian (2000), the instrument of a research is a tool that used in data collection. In this research, the researchers used writing test, for pretest and post test. The model of test is writing explanation text. In the pre-test, the sample was required to write an explanation text. The last, the sample was required to write the explanation text again in post-test.

In the writing test, the students got several topics from the researchers such as flood, rainbow, global warming, and tsunami as the option, so the students can choose one of them to be their writing topic. The test was done in 40 minutes. The researchers also gave the instruction about test that used extensive reading and then the students wrote down their result into paragraphs from their extensive reading.

This research was conducted through some procedures orderly, they are try tryout, treatment and post-test. Tryout was conducting in different group of the control and experimental groups. It was aimed in measuring the quality of the test before it was used in the pre-test. The pre-test was aimed at knowing those groups basic competence in writing explanation text. The treatment was giving in different technique which the experimental group was taught by using extensive reading while the control group was not. Last, conducting post-test was aimed at checking the students improvement after getting treatment.

The data in this research was processing and analysing by using SPSS program. The tryout test was used to analyze the validity and reliability of this research. The validity in this research was content validity which means that the test sufficiently representative the same manner as in curriculum. There writer's advisor and the English teacher of Islamic School in Semarang who validated the content validity form. Meanwhile, the reliability of the research used ratter reliability which also means that there are more two scorers who give the score to the test. The first one was the writer and the other one was the English teacher of Islamic School in Semarang. In SPSS program, it used Spearman Rank Correlation to analyze the reliability result. Then, the result of pre-test was used to analyze the homogeneity and the standard normality. The homogeneity used Levene Test for Equality of Variences while the standard normality used One-Sample Kolmogrov-Smirnov. Last, the result of post-test was used to calculated the result of T-Test. It used Independent Samples Test on SPSS program to process the T-Test result 
Aida, S.N., \& Widiyati, E. (2020). Extensive reading to improve students' writing skill of explanation text. EduLite: Journal of English Education, Literature, and Culture, 5 (1), 109-117.

\section{RESULTS AND DISCUSSION}

This research was conducted at the eleventh grade students of Islamic School in Semarang in the academic year 2018/2019. The number of sample of respondents was 65 students. It consisted of 31 students as the control class and 34 students as the experimental class.

As mentioned on the previous chapter that this research used test in collecting the data especially written test. It conducted at pre-test and posttest. But before the test in the pre-test and post-test are conducted, tryout was done first. In this research, tryout was held on May 13th, 2019. The result was to analyze the validity and reliability in this research. Reliability is important characteristic of good instrument. The reliability of this research was measured by using Spearman Rank Correlation. According to Bungin (2006), If the obtained value is higher that table t-value, the test can be stated reliable. The result showed that coefficient was 0.966 and sig.(2-tailed) was $0.000<$ 0.05 . Therefore, the instrument of this research was very high reliable. The table of result of output of SPSS can be seen below (table 1):

Table 1. Inter-rater Reliability of Try-out Class Correlation Reliability Statistics

\begin{tabular}{cc}
\hline Cronbach's Alpha & N of Items \\
\hline .966 & 2 \\
\hline
\end{tabular}

Pre-test was conducted on May 15th, 2019 for control class and the experimental class. The result of the pre-test was used to analyzed homogeneity and standard normality. Homogeneity used Levene's Test for Equality of Variances which the criteria were if sig (2-tailed) $>0.05$, it means that the sample is homogenous, meanwhile if sig (2-tailed) $<0.05$, it means that the sample is not homogenous. Table below shows the homogeneity result:

Table 2. Homogeneity of Variances

\begin{tabular}{cccc}
\hline Levene Statistic & df1 & df2 & Sig. \\
\hline 1.274 & 6 & 23 & .307
\end{tabular}

Table 2 shows sig. value for experimental and control groups were 0.307 which it more than 0.05. Therefore, it can be concluded that the students' variance of both of the groups were same.

In analysing the standard normality, it used One-Sample KolmogrovSmirnov which the criteria of hypothesis were; if the sig (2-tailed) $>0.05$, it means that the distribution is normal, meanwhile if sig (2-tailed) $<0.05$, it means that the distribution is not normal. Then, the result shows that the significance value of experimental group was 0.536 , while the significance value of control group was 0. 155. Because both of the group results were more than 0.05, it means that the data of both of the groups were normal. The table of the standard normality test result can be seen on the table below: 
Table 3. Standard normality

One-Sample Kolmogorov-Smirnov Test

\begin{tabular}{llrr}
\hline & & Experimental & \multicolumn{1}{c}{ Control } \\
\hline $\mathrm{N}$ & & 31 & 34 \\
\hline Normal Parameters & & 50.6452 & 55.2941 \\
\cline { 2 - 4 } & Mean & 10.06164 & 10.86705 \\
\cline { 2 - 4 } Most Extreme & Std. Deviation & .203 & .138 \\
\cline { 2 - 4 } Differences & Absolute & .203 & .126 \\
\cline { 2 - 4 } & Positive & -.145 & -.138 \\
\cline { 2 - 4 } & Negative & 1.130 & .805 \\
\hline Kolmogorov-Smirnov $Z$ & & .155 & .536 \\
\hline Asymp. Sig. (2-tailed) & & &
\end{tabular}

a. Test distribution is Normal.

The post test was done on May 29th, 2019, its result was used to analyze T-Test. It was aimed at proving whether the use of spinningwheel is significant or not. The significant level was 0.05 with the criteria: if $t$-value $>\mathrm{t}-$ table and sig (2-tailed) $<0.05$, it means that $\mathrm{Ha}$ is accepted and Ho is rejected whereas if $\mathrm{t}$-value < t-table and sig (2-tailed) $>0.05$, it meant that $\mathrm{Ha}$ is rejected and Ho is accepted. The result table of output of SPSS can be seen on the following:

Table 4. The result of post-test

\begin{tabular}{|c|c|c|c|c|c|}
\hline & Post_test & $\mathrm{N}$ & Mean & $\begin{array}{c}\text { Std. } \\
\text { Deviation }\end{array}$ & $\begin{array}{c}\text { Std. } \\
\text { Error Mean }\end{array}$ \\
\hline \multirow[t]{2}{*}{ Score } & Experimental & 31 & 64.41 & 10.01612 & 1.79895 \\
\hline & Control & 34 & 48.54 & 15.50976 & 2.65990 \\
\hline
\end{tabular}

Table 5. Independent Sample Post-test In Control and Experimental Class

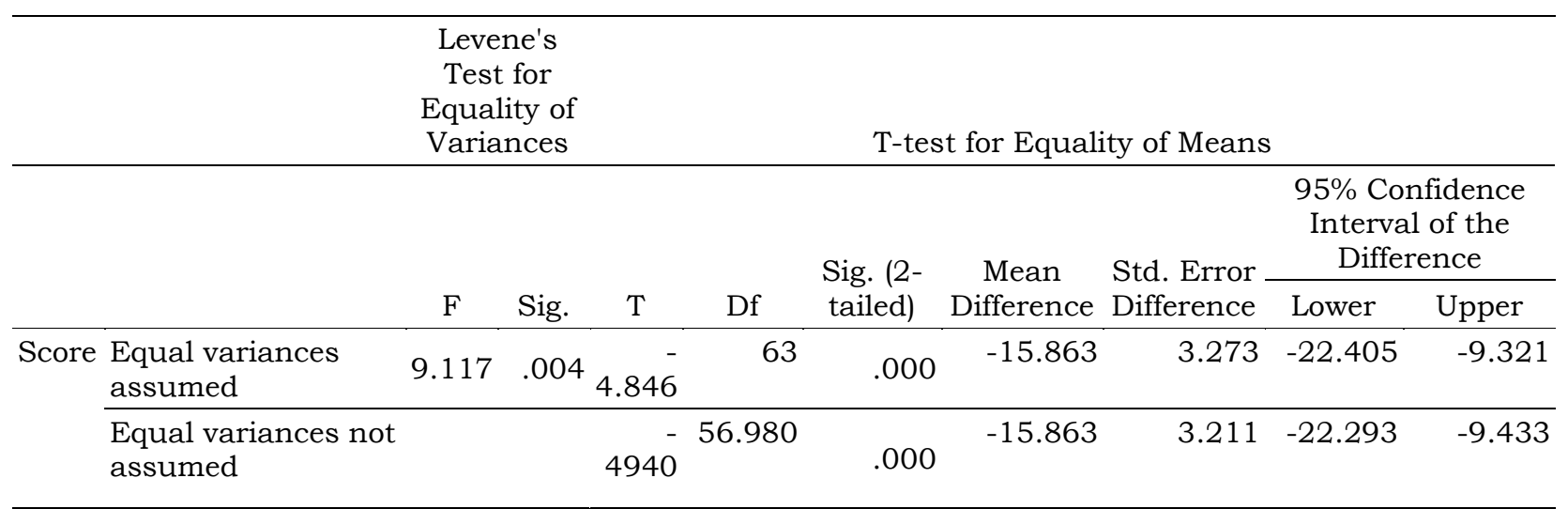

Based on the first table above, it can be seen that the mean score of the experimental group was 64.41 while the control group was 48.54 . It can be stated that the result of the experimental group was higher than the control group. 
Aida, S.N., \& Widiyati, E. (2020). Extensive reading to improve students' writing skill of explanation text. EduLite: Journal of English Education, Literature, and Culture, 5 (1), 109-117.

Furthermore, the result of the Independent Sample T-Test can be seen on the second table. The Independent Sample Test showed that Sig. (2-tailed) was $0.00<0.05$. It means that $\mathrm{H}_{a}$ was accepted. Then, it can be concluded that extensive reading as teaching technique was effective to teach writing explanation text.

\section{CONCLUSION}

After all, the students' mastery of explanation text by using extensive reading improved after the treatment was given. Moreover, Sig. (2-tailed) showed 0.00 $<0.05$ which means that $\mathrm{HO}$ was rejected and $\mathrm{H} 1$ was accepted, whereas teaching writing explanation text by using extensive reading in the experimental class influenced the students' ability and it was considered to be effective in improving explanation writing skill. It could be concluded that the use of extensive reading to teach writing explanation text was effective. Therefore, extensive reading as teaching technique was really effective to teach writing explanation text and could help students to improve their ability in writing explanation text.

\section{ACKNOWLEDGMENT}

We would like to appreciate for the chance and the assistance coming from the Dean of Languages and Science Communication Faculty, Mr. Hartono, for this publication, moreover for the special gratitude to Mrs. Huyi Intan Sari as the Head of English Education Study Program.

\section{REFERENCES}

Aghanjaloo, K., Mobini, F., \& Khosravi, R. (2016).The effect of teachers ${ }^{\text {e }}$ written corrective feedback (WCF) types on intermediate efl learners ${ }^{\text {ee }}$ writing performance. Advances in Language and Literary Studies, 7, 2837. doi: 10.7575/aiac.alls.v.7n.3p.28.

Al-Mansour, N. S., \& Al-Shorman, R. A. (2014). The effect of an extensive reading program on the writing performance of Saudi EFL University Students. International Journal of Linguistics, 6(2), 247. https://doi.org/10.5296/ij1.v6i2.5551

Brown, H. D.(2011). Listening myths: Applying second language research to classroom teaching. Ann Arbor: University of Michigan Press.

Chinelo, I. (2016). <Fundamentals of Research Methodology and Statistics.pdf $>$, (May 2015), 19-21. Retrieved from https://www.researchgate.net/profile/Jayanta_Nayak2/publication/309 732183_Fundamentals_of_Research_Methodology_Problems_and_Prospec ts/links/582056a208aeccc08af641dc/Fundamentals-of-ResearchMethodology-Problems-and-Prospects.pdf

Cohen, L. \& Manion, C. (2018). Research Methods in Education. (5th edition). London: Routledge Fahner 
Fauziati, E. (2014). Methods of Teaching English as a Foreign Language (TEFL). Surakarta: Era Pustaka Utama.

Kigotho, M., \& Fitriani, S. S. (2018). Summarising an explanation text with a visual representation as the guidelines: How does this work to represent meaning? Al-Ta Lim Journal, 25(1), 1. https://doi.org/10.15548/jt.v25i1.379.

Mukherjee, M. (2017). A Review of research design. International Journal of Advanced Engineering and Management, 2(3), 56. https://doi.org/10.24999/ijoaem/02030016

Pandey, P., \& Pandey, M. M. (2015). Research methodology: Tools and techniques (1st ed.). Romania: Bridge Center.

Sakurai, N. (2017). The Relationship between the amount of extensive reading and the writing performance, 17(2), 142-164.

Salehi, H., Asgari, M., \& Amini, M. (2015). Impacts of the extensive reading texts on the writing performance of Iranian EFL Pre-university Students. Asian Journal of Education and E-Learning, 03(04), 306-316. 